\title{
Worlding Cities Through Transportation Infrastructure
}

\begin{tabular}{|r|l|}
\hline Journal: & EPA: Economy and Space \\
\hline Manuscript ID & EPA-2017-0308.R2 \\
\hline Manuscript Type: & $<$ font color="\#0066cc" > Original Manuscript $<$ /font color $>$ \\
\hline Keywords: & worlding, heritage, governance, transportation infrastructure, Malaysia \\
\hline
\end{tabular}

\section{SCHOLARONE \\ Manuscripts}




\title{
Worlding Cities Through Transportation Infrastructure
}

\author{
Creighton Connolly, Asia Research Institute, National University of Singapore
}

\begin{abstract}
:
This paper engages with emerging literature on worlding cities in analyzing the contested ways in which mid-sized cities attempt to 'globalize' through the redevelopment of urban infrastructure, and in particular, transportation infrastructure. The paper focuses specifically on the World Heritage City of Penang, Malaysia and critically examines controversies over the extensive urban redevelopment and regeneration projects that have emerged since 2012. In particular, it examines the ambitious Penang Transport Master Plan (PTMP), which has posed considerable implications for the city's heritage landscapes, but also several socio-environmental impacts. The paper analyses the State Government's vision for the PTMP, before turning to an alternative strategy and critique of this plan put forth by local civil society organizations. As I demonstrate, both plans make use of worlding strategies in 'selling' their particular vision for the city's future, but the way in which they do so is markedly different. In reviewing this case, the paper challenges the conceptualization of inter-referencing and urban modeling practices as it is currently documented in the literature on worlding cities. What is novel in Penang is the way in which local stakeholders identify comparable cities outside of the global North as models to follow, rather than established mega or 'world' cities, which act as more realistic reference points. In doing so, the paper highlights key technologies of governance that are being used to counter the neoliberal worlding strategies put forth by city managers.
\end{abstract}

Keywords: worlding, transportation infrastructure, planning, governance, heritage, Malaysia

\section{Introduction}

"We want to become an international, intelligent city that is clean, green, safe and healthy, brimming with energy, expertise and entrepreneurship...If we have that, we will be the model state for the rest of Malaysia,"

(Penang Chief Minister, Lim Guan Eng, in Ng, 2016: np).

In the quotation above, former Penang Chief Minister Lim Guan Eng expressed his vision of transforming Penang into an 'world-class international city' by 2021 (Ng, 2016). To do that, his government is planning a \$US 6.3 billion dollar upgrade of transport infrastructure in the island-city, known as the Penang Transport Master Plan (PTMP, which would consist of new highways, light rail transit (LRT) and monorail lines, cable cars, new buses and a $2 \mathrm{~km}$ undersea tunnel linking Penang island to the Malaysian mainland. If given the approval by the federal government, Lim suggested that Penang could be "a showcase of modern Malaysia", and "be well on its way to a global city that could 
rival Singapore" (Ng, 2016: $\mathrm{np})$. Yet, there is a fundamental tension and incompatibility between the city's 'global city' aspirations (and associated mega-development projects), and the realities of its existing landscape, infrastructure, and finances, which has become been a major source of concern for local residents and civil society activists.

Thus, the Penang Forum, a coalition of local NGOs have put forward a detailed critique of the plan, and alternative proposal, encapsulated by the slogan 'Better, Cheaper, Faster'. This plan calls for less new infrastructure and advocates for more accessible and affordable mode of transit, oriented around bus and tram systems that would address Penang's transportation needs in a more efficient and socio-environmentally just manner. Rather than viewing that is a failure of Penang to 'catch up' to other mega and global cities on such rankings, grassroots organizations in Penang have expressed the desire for Penang to be an 'ordinary city' that is based on other modes of being 'global' (c.f. Bunnell, 2004; Robinson, 2002).

In contrasting these competing visions for Penang's future, this paper analyses how the government and civil society groups in Penang invoke and articulate different worlding strategies through their respective plans. It also demonstrates how participatory approaches to urban planning can identify and put forth alternative models of urban development that are more socially and environmentally just than the standard global city strategies often favored by city leaders. Such approaches are urgently needed, as Robinson (2002) noted long ago that the dearth of alternative vocabularies and strategies severely limits imaginations of possible futures for urban policy makers. Indeed, as Douglass (1998) has cautioned, calculated attempts at world or global city formation can have devastating consequences for most people in the city. For instance, the PTMP plan was delayed by the Federal Government's initial refusal to sign off on the massive land reclamation needed to finance the project, given that it would jeopardize the livelihoods of 1,500 fishermen in the area (Ngui, 26 August, 2017). ${ }^{1}$ This paper thus attempts to further develop the concept of 'worlding cities', initially put forth by Simone (2001) and subsequently developed by Ong and Roy (2011), by tracing alternative formulations of worlding which draw inspiration from a wider range of urban contexts beyond the usual roster of world, global or mega-cities.

Despite offering a useful concept for understanding the emergence and formation of worlding practices, the literature on worlding is still in a nascent stage of development. Roy and Ong (2011:4) note that a "striking aspect of Asian urban transformations involve seemingly unavoidable practices of

\footnotetext{
${ }^{1}$ This was prior to the May 2018 federal election in which the incumbent government lost to a coalition of parties including that which governs Penang state.
} 
inter-city comparison, referencing or modeling". Yet, the cases that they include largely make reference to established global and world cities, including Singapore, Hong Kong, Vancouver and Dubai. In contrast, the case of Penang demonstrates how civil society actors have cast their sights 'outwards' to comparable cities around the world, rather than merely 'upwards' to global and mega-cities that can simply not act as viable models of Penang's future. In this way, the paper contributes to developing a concept of wording that can assist in imagining possible city futures beyond the experiences of select world and global cities.

Transportation planning in particular is one form of situated practice shaping the urban politics and imagined future of Penang and other globalizing cities, but this has yet to be recognized in the worlding cities literature. It is nonetheless important as many cities in the global South are now experiencing immense transport-related challenges, including pollution, congestion, and accessibility. Indeed, transportation planning has been addressed in the policy mobilities literature to illustrate how particular cities serve as 'models' to be replicated, and the production of alternative policy projects, visions and strategies outside of the 'global North' (Peck and Theodore, 2010; Wood, 2014). However, this literature has to date had little engagement with that on worlding cities. Furthermore, mid-sized cities are especially important because they are the fastest growing regions, particularly in Asia and Africa, and yet typically lack the resources and capacity to manage this growth (Pojani and Stead, 2015: 7785).

The next section situates the paper within the relevant literature on worlding cities, and interreferencing in particular. It also introduces some literature on transportation planning and how it is important for understanding the forms of worlding and inter-referencing strategies being used in this case. I then turn to the literature on urban governance to further contextualize the form of civil society and governance initiatives analyzed here. In particular, I revisit the concept of civic governmentality, developed by Roy (2009), to evaluate the potentialities and limitations of grassroots worlding practices. I also discuss the methodological approach and methods used in carrying out this research, before turning to the empirical content. This is divided into two main sections, one reviewing the Penang State Government's plans for the PTMP, and the other examining the alternative plan put forth by local civil society organizations. I conclude by reflecting on the main findings of the paper, and how they contribute to understanding the forms of (competing) wording and inter-referencing strategies that are used in the development of transportation infrastructure.

\section{Global, world and 'worlding' cities}


It is now widely recognized that dominant approaches to urbanization, with a focus on global/world city making, impose substantial limitations on imagining or planning the futures of cities around the world (see, e.g. Robinson, 2002). This paper builds on a growing body of literature that has unsettled former conceptualizations of global or world cities as a set of qualities confined to a select few cities, rather than a broader set of relations inherent in all cities (Baker and Ruming, 2013; Blok, 2014; Robinson, 2002). This could be labelled the 'worlding' turn in the literature on global/world cities, which has sought to theorize the contingent relations, aspirations and worlding practices that are at play in many developing and mid-sized cities around the globe (Roy, 2011; Ong, 2011). In doing so, existing literature on wording cities has focused on the various discourses, practices, and aspirations that are mobilized by urban stakeholders in articulating particular urban or 'global city' futures (see Baker and Ruming, 2015; Blok, 2014; McCann et al., 2013; Ong, 2011). Work on worlding cities has also been successful at "decenter[ing] elite actions, imaginations and aspirations in the (re)making of cities" (Bunnell and Marolt, 2014: 382). However, this literature is still at a relatively nascent stage, and further understanding of the particular strategies used in doing so require further nuance and specificity.

While Roy and Ong (2011) offer a compelling framework for theorizing the types of inter-city referencing characteristic of urban wording strategies, I argue that the geographies of these practices have not been adequately theorized. The examples in their landmark book, Worlding Cities: Asian Experiments and the Art of Being Global, highlight inter-referencing strategies as one key form of worlding strategies used. As such, the book contains several chapters illustrating the forms of interreferencing strategies used by developing cities which aspire to be Vancouver, Singapore or Shanghai. While this work has been useful in shifting attention away from established 'world cities' in Western countries, the geographies of such flows are still much more nuanced. This is a point recognized though not fully addressed - by McCann et al. (2013) who call attention to the shifting genealogies of worlding cities. This paper therefore takes up this call by opening up the "restricted spatialities" of worlding cities, and developing a more cosmopolitan account of how city-making operates (Robinson, 2002: 532). In doing so, it builds on Robinson's (2002) concept of 'ordinary cities', in order to further understanding of the substantial range of potential international or transnational connections that characterize inter-referencing practices in cities outside of the global North.

In recent years, research on the worlding of cities have now begun to identify and conceptualize different forms of worlding and inter-referencing strategies that can be found in disparate urban sites. For example, Blok (2014) has traced the worlding of cities through climate projects in three very different cities from around the world. This paper is useful for pin-pointing the trans-local relations 
responsible for the sustainable redesign of the built environment of cities. In doing so, it illustrates the situated practices and new 'climate solidarities' that are (re)shaping "less iconic, though regionally significant" mid-sized world cities, such as Kyoto, Japan and Surat, India. In another example, Baker and Ruming (2015) examine how particular actors have sought to globalize Sydney through strategic spatial plans and governance strategies, especially through reference to other global cities such as London, Vienna and Mumbai. More recently, Wood (2014) and Montero (2017) have demonstrated how Bogotá has become an international model of urban transportation 'best practices' by tracing particular urban interventions implemented by local policy makers.

The focus on transport infrastructure in particular as a wording strategy has been adopted by other aspirational world cities, like Sydney, which emphasize the development of transport corridors, transport hubs and networks in order to reduce car dependence (see Baker and Ruming, 2015: 74). While progressive transport strategies implemented in cities of the Global North often circulate amongst planners in transitioning economies- including Penang - it is often not feasible for such cities to replicate them. This is primarily due to differences in the finances available for the implementation of transport infrastructure, as well as in population sizes. Indeed, as Graham and Marvin (2011:12) have argued, the way in which the contested politics of infrastructure development play out in each city, region or nation is still closely related to the broader constructions of governance, the state, and the market in each case.

As Pojani and Stead (2015) have observed, policy transfer in the urban transport arena is thus subject to a range of different (political, institutional, socio-economic) influences, meaning that there is limited prospect of transferring policies beyond national boundaries. However, they also note that Latin American cities have been quite successful at developing efficient and cost-effective public transport systems, and can thus serve as more realistic models to implement (see also, Montero, 2017). Therefore, as I will discuss in the following section, civil society groups in Penang have sought to implement examples from a variety of global contexts in articulating a feasible transport plan for the city.

\section{Grassroots approaches to worlding cities}

Like much of the worlding cities literature discussed above, this paper intends to demonstrate not only how urban policy is formulated 'from above' in rapidly globalizing Asian cities, but also how alternative wording aspirations are being pursued 'from below' through grassroots movements (see also Roy, 2011; Simone, 2001). While the effects of alternative, grassroots planning initiatives are arguably limited by inequalities of power and resources, they nonetheless provide an opening for various actors 
to contest the dominant urban trajectories promoted by city leaders (see, Blok, 2014; McFarlane, 2011; Shatkin, 2011). For instance, as Chatterji (2005: 206) has demonstrated, governmental development plans and visions do not always form a seamless whole, but may include "gaps that allow for new connections and relationships". As I will illustrate in the next section, the Penang case demonstrates how civil society actors are able to infiltrate these gaps to alter the course of the government's plan for the PTMP.

This focus on grassroots governance initiatives is important to identify pathways towards inclusive and sustainable cities that go beyond world-making strategies used by city managers. As we will see in the next section of this paper, civil society groups in Penang have emerged in a bottom-up fashion, in order to increase accountability on behalf of the government, while also resisting development plans that are perceived as detrimental to the public interest. Moreover, building on the work of Bunnell and Marolt (2014), the focus on worlding practices here demonstrates that senses of socially and politically possible futures - while rooted in (and thereby shaped by) local cultural conditions - are also equally influenced and inspired by experiences elsewhere.

Recent critiques of urban governance regimes have argued that while the broadening of the political sphere over the past three decades has been good in principle; it has in practice been characterized by a lack of true democratic principles, due to the neo-liberalization of states and promarket policies (Swyngedouw, 2005). This relates to the rescaling of state power from the nation-state to urban region, and the resultant entrepreneurial strategies adopted by city governments (see Allen and Cochrane, 2007; Bunnell, 2004). Consequently, rationalities of planning and democratic governance are compromised as city governments bow to various developmental and political pressures.

In discussing the potentialities and limitations of grassroots worlding practices, I revisit Roy's (2009) concept of civic governmentality, which she developed to examine the institutionalization of participatory citizenship regimes. While this is an important concept for understanding how forms of participation and inclusion are institutionalized in urban contexts, it has largely been applied to cases of 'bourgeois environmentalism' to document how elites are able to de-politicize urban governance processes (see Baviskar, 2003; Ellis, 2012; Ghertner, 2011a; Swyngedouw, 2005; 2009). Moreover, most of the cases have been specific to the Indian context, which has its own particularities regarding the role of elite or bourgeois 'NGOs'. On the contrary, I aim to illustrate the technologies of governance used by civil society actors in Penang to counter the worlding strategies adopted by the State Government. These include various forms of knowledge production, public consultations, and public campaigns. While many of the actors involved in grassroots movements in Penang can also be classified as elites from (upper) middle class backgrounds, the movements have been much more 
participatory than described by Roy. Nonetheless, as I will demonstrate, the Penang case does reveal the limits of grassroots worlding practices, which is in part due to their largely reactionary nature.

Furthermore, while the State Government does make some attempt at incorporating civil society interests, this has been in practice quite limited. This can be seen in the fact that only one seat in the Penang Island City Council (Majlis Bandaraya Pulau Pinang - MBPP) - out of 24 - is reserved for a nominated representative from local civil society groups. They may also be removed if they are deemed to be too outspoken in criticizing the State Government. Moreover, one interviewee from the MBPP lamented that development decisions are largely made by the State Planning Committee, and handed down to the city council 'for information only' (See Netto, 2017). As such, this paper identifies the various challenges that Penang civil society have faced in articulating and achieving their vision for the future, and how they may be overcome.

\section{Methods for tracing the worlding strategies of cities}

The research for this paper is part of a broader project examining the spatial transformations associated with Penang's infrastructural projects and their social and ecological effects. It has used ethnographic, participatory methods in evaluating the role of civil society actors in both resisting and actively co-producing new developments in an attempt to (re)shape the city in both sustainable and culturally distinctive ways. The research has been participatory in that the particular controversies and questions asked in the project have been developed in consultation with local actors over an extended period of time. This has emerged from ongoing research in Penang over the past five years, which has generated a significant amount of rapport between myself as researcher and many of the primary participants in this project. Furthermore, one of the intended outputs of this project is to contribute research to ongoing participatory planning initiatives in Penang in an attempt to resolve some of the controversies examined here.

The data presented in this paper is derived from approximately 22 semi and unstructured interviews with city planners, government representatives, city councillors, heritage activists, and other civil society members in Penang from August 2016 through July, 2017. I have also conducted a discursive analysis of official planning documents, alternative plans put forth by civil society groups, and public statements from a range of different actors. This includes the official proposal for the 
PTMP, developed by the SRS Consortium, which was made available to the public in early 2017; as well as the alternative 'Better Cheaper Faster' plan for the PTMP put together by the Penang Forum. ${ }^{2}$

The planning documents are important to demonstrate, as Baker and Ruming (2015: 63) put it: "how strategic spatial plans are themselves sites of worlding, serving as expressions and agents of global urban imaginaries in their own right", as well as the variety of actors and institutions involved in wording cities. In this sense, they can help respond to Shatkin's (2011) call for further understanding on the particular strategies and discourses that state and private sector actors use to move urban megaprojects forward, and to channel investment into particular spaces, places, and activities (see also Wetzstein, 2013: 75). Furthermore, the alternative proposals put forward by civil society critiques serve to illustrate how more participatory approaches to planning might identify alternative models of development that are more appropriate to the local context than official planning documents (see Mulligan et al., 2012). Additionally, I have been a part of Facebook and WhatsApp Groups dedicated to the discussion of (re)development, heritage and planning issues in Penang, initiated by civil society groups. As one member of the WhatsApp discussion candidly noted, "if anyone wants to understand the concerns and hopes of any place, this is the kind of information which needs to be carefully consulted and reflected on...because we need to know what the citizens think and what they want" (Eric, 29 May 2017). ${ }^{3}$

\section{Penang and the Transport Master Plan}

The PTMP was actually an idea proposed by the civil society to the Penang State Government in 2009 in order to reduce congestion and increase the use of public transport in the city. In response to this request, the Penang State Government then hired Transport Consultants Halcrow to develop a plan for the PTMP with the stated objective of "adopting a balanced approach for public transport and highway improvements" (Penang State Government, 2016: np). Halcrow is an international consultancy with recognized international credentials and a long track record in the fields of transportation infrastructure development and analysis. However, one month before Halcrow was appointed for this proposal, the State Government signed a memorandum of understanding (MOU)

\footnotetext{
${ }^{2}$ However, it should be noted that the State Government only made an outdated version of the SRS Consortium's original 'Request For Proposal for the PTMP', rather than the most recent and official plan for the PTMP.

${ }^{3}$ For a discussion on the use (and limitations) of emergent forms of internet ethnography in studying urban aspirations amongst 'everyday' actors, see Liew and Pang (2015). Names cited here are pseudonyms, unless otherwise requested by the person quoted.
} 
with the the Zenith-BUCG Consortium which stated that the consortium would build three new highways on the island, and one undersea tunnel, costing RM6.3 billion (Ringgit Malaysia). ${ }^{4}$ Then, in 2013, Halcrow completed its detailed study of Penang's transport needs and produced its final report and proposal, which was adopted by the State Government at a cost of RM3.2 million. Subsequently, the Penang State Government sought a Project Delivery Partner which would be responsible for implementing the Halcrow Plan for the PTMP. Six proposals were received, and the SRS Consortium won the bid, ${ }^{5}$ but with a different proposal which was not based on the Halcrow report.

Both the SRS and BUCG consortiums specialize in property development and construction, and not surprisingly developed very capital intensive transport models in their proposals. For instance, the numerous modes of transportation infrastructure envisioned by the plan would cost RM46 billion and would be partially funded by reclaiming more than 4,000 acres of land off the southern, northern and eastern coasts of Penang. The largest of these schemes is known as the Southern Reclamation Scheme (SRS), which is a self-contained urban district, consisting of residential, commercial, industrial and office space spread across three connected islands off Penang's Southern Coast. This is what Shatkin (2011) has referred to as an urban-integrated mega project (UIM), which are large-scale, for-profit development projects often proposed and constructed by a single developer. There is also a large piece of land (110 acres) currently being reclaimed along the northern coast of Penang Island - known as Sri Tanjung Pinang (STP) - which was allotted to Zenith-BUCG as payment in kind for the feasibility study, design and construction of the RM6.3 billion undersea tunnel and new highway developments envisioned by the SRS Scheme for the PTMP. However, these consortiums lack expertise in the construction and development of infrastructure, which is a major point of concern (Britton, 2016: 8)

In particular, the state vision for the PTMP consists of seven different components. This includes various public transport systems, including an LRT line from George Town to the airport, approximately 19 kilometers to the south. There are three further monorail lines planned from George Town to Air Itam, near the center part of the island; George Town to Tanjung Bungah on the northern coast; and another connecting different communities on the mainland side of Penang state (Seberang Perai; see figure 1). There is also a 'tourist tram' planned to operate within the George Town World Heritage Site, as well as a BRT (Bus Rapid Transit) system planned within Seberang Perai. As mentioned above, there are two pan-island highways planned, which SRS designed to emulate

\footnotetext{
4100 Malaysian Ringgit = approximately US\$25

${ }^{5}$ SRS Consortium is comprised of three different companies, Gamuda (60\%) - an infrastructure company; Ideal Property Group (20\%) - a Penang developer; and Loh Poh Yen Holdings (20\%) - a Penang Property Company.
} 
Singapore's highway scheme, and an undersea tunnel to be developed by Zenith-BUCG. Furthermore, the plan calls for additional road widening and upgrading along the north coast of Penang island and an expressway connecting towns along the Mainland side of the State. Finally, and perhaps most controversially, there is a plan to build a 'sky cab', which would turn Penang Hill into a transport hub, connecting George Town, Air Itam and Tanjung Bungah via cable car. ${ }^{6}$

<Figure 1 about here: Map of George Town and Penang State. Photo Credit: "Penang Wikivoyage Map"; Wikimedia Commons user Torty3; (https://commons.wikimedia.org/w/index.php?curid=31257157); image reproduced under a Creative Commons license.>

According to the official government website for the PTMP, the central premise of the state's strategy is to "move people, not vehicles" (Penang State Government, 2016). However, as one interviewee told me, a similar slogan ("move people, not cars") was actually put forth by civil society members first in putting forth their vision for the PTMP (interview, 11 August 2016). As such, the government has now co-opted this slogan as a means of promoting the capital intensive public transport components proposed for the PTMP, and appeasing civil society groups. Moreover, the same interviewee noted that there were no public consultations undertaken in the development of the SRS proposal. This is something that local civil society actors have sought to contest through pushing the State Government to live up to their own slogan of 'competent, accountable and transparent', while also organising public forums to solicit feedback on the various plans for the PTMP.

The original Halcrow proposal was indeed favored by civil society groups, given that it put forward a 'holistic approach' which aimed to improve (but reduce) private transport and increase public transport, as well as funding pedestrian and cycling infrastructure. However, the SRS proposal argued that it was "aspirational but not realistic", as it did not provide any recommendations on how to finance the proposal, which would cost RM27 billion (SRS Consortium, 2015: 2). 3 billion of this was slated to come from the State Government, with the federal government and private sector making up the remaining 24 billion. This was seen as unfeasible, given that Penang was at the time controlled by the federal opposition Democratic Action Party, and therefore only received limited financial support from

\footnotetext{
${ }^{6}$ Though, as one interviewee noted, this plan is not likely to go through due to a lack of funds on behalf of the State Government.
} 
the Federal Government. ${ }^{7}$ Therefore, the SRS and Zenith-BUCG proposals sought more entrepreneurial means of funding the infrastructure projects, while also aiming to boost economic growth.

The Penang State Government's endorsement of such plans arguably stem from the the Malaysian nation-building project which has raced to develop material icons of 'modernity' like Putrajaya - Malaysia’s planned administrative capital, or the Petronas Twin Towers in Kuala Lumpur (Bunnell, 2004). In this way, 'modernity' in Malaysia is expressed primarily through the construction of buildings and other infrastructure that is, "the tallest, the biggest, the longest and the widest" (Jenkins and King: 2003: 45). As various urban scholars have observed, such infrastructural projects arise from the shift in governance from the national scale towards subnational scales, making entrepreneurial urban governance more prevalent and important (see Baker and Ruming, 2015; Brenner, 1999). In other words, urban governance has become characterized by an emphasis on economic growth and inter-urban competitiveness (see Hall and Hubbard, 1998; Harvey, 1989). As Barau (2017) has noted, this has been particularly pronounced in small and medium cities which have become primary targets for economic growth and massive landscape transformation.

Civil society groups in Penang have thus challenged the SRS and Zenith-BUCG plans for the PTMP, recognizing that Penang can not realistically replicate the development trajectories of established global cities, and are thus seeking a more liveable city that retains its unique heritage landscapes. In particular, the Better, Cheaper, Faster report argues that Penang should tailor its investments according to its resources, and that "it is foolhardy to overreach and embark on mega projects that could be financially unviable and plunge the people of Penang...into debt and financial distress" (BCF 2016: 19). For this reason, as I will demonstrate in the next section, the BCF report uses primarily smaller, secondary cities in other Asian and Latin American countries as examples to follow in (re)developing its transportation infrastructure, rather than 'global' or mega cities.

\section{'Better, Cheaper, Faster': An alternative plan for the PTMP}

The Penang Forum is a loose coalition of NGOs in Penang, which aims to "promote participatory local democracy, sustainable planning and development, economic justice, affordable housing, environmental consciousness, sustainable transport, workers' rights and heritage conservation" (Penang Forum, 2012). It was formed between 2007 and 2008 through civic responses to previous development

\footnotetext{
${ }^{7}$ In addition to its political status, this is due to the fact that Penang is comprised of mostly Chinese ethnic Malaysians, rather than Malay-Muslims, which are dominant in most other states and control much of the federal politics (see Bunnell, 2002).
} 
initiatives in Penang, notably the anti-Penang Global City Centre Project of 2008. The Penang Forum has a steering committee which plans events and campaigns, but is not dominated by one individual or group. The group gets its name from the regular public forums which are held to get input from concerned residents on local development and conservation issues. This is one means by which regimes of participation and inclusion are institutionalised through the Penang Forum, which allows for debating the proposed development plans. Many of the members communicate informally through various WhatsApp groups, including the 'Sustainable Penang' group, which incorporates a number of people including government officials, civil society members, and researchers interested in sustainable development in Penang. As mentioned above, these groups are a primary way for a variety of people interested in sustainability, inclusivity in the Penang context to discuss relevant issues and share viewpoints.

Key organizations contributing to the functioning of the Penang Forum are the Penang Heritage Trust, the Consumers Association of Penang, and Sahabat Alam (Friends of the Earth) Malaysia. There are also a number of individuals on the steering committee who are not directly involved with these groups, including locally based architects, scientists and writers. Most members of the Forum are Penangites, but there are a small number of locally based expatriates. As mentioned earlier, the Penang Form is also entitled to elect one individual to serve on the Penang Island City Council, which gives the organization some power at the city level. The range of professional skills among Penang Forum members also gives them some credibility with the government because their members can provide expertise which is lacked by the State Government and City Council. As pointed out by other scholars (see Barber, 2013; Hezri, 2016; Ku, 2012) this is increasingly common way in which urban governance relationships are changing, with the increasing prevalence of 'citizen professionals' who have taken up responsibility in the co-production of cities (Christof, 2018). In particular, it is a means by which civil society groups have sought to challenge the authority of the state in the area of knowledge production which has been central to the governmentally of the developmental state (Ellis, 2012; Swyngedouw, 2009; c.f. Roy, 2009).

Through this assemblage of expertise, the Penang Forum has thus put forth an alternative plan for the PTMP which they have named 'better, cheaper, faster' (hereafter 'BCF', Penang Forum, 2016a). The proposal has been branded as such to try to mobilize greater support for the plan, and to educate the broader population about the benefits that it would have for Penang. This has been done through the creation of a website (www.bettercheaperfaster.my), Youtube videos, online petitions, and other social media campaigns (e.g. Facebook). Such media can be seen as another technology of governance 
employed by the Penang Forum in attempting to enlist a greater numbers of people to resist the State Government's plans for the PTMP.

According to the Penang Forum, their plan is better because it is more accessible for all users; has a smaller carbon footprint (more environmentally friendly); is quieter and produces less vibrations (less of a nuisance); and it is flexible and hence much easier to expand in the future. It is cheaper, at half the price to build, cheaper to expand in the future, and two to three times cheaper to operate and maintain than the proposed LRT and Monorail systems. Finally, it is faster as modern tram and BRT systems are twice as fast to construct. The BCF document starts out by reviewing the shortcomings of the SRS proposal for the PTMP, before moving on to the alternative vision for Penang, which I will now outline, in turn, below.

The BCF report has argued that the official PTMP plan is trapped in an 'old paradigm' of building more roads, and building public transport based on outdated technologies. Instead, it argues that world leading cities are those that are taking steps to constrain rather than promote private transportation in cities, reducing carbon emissions, and exploring new technologies for electric and automated personal and public transportation (BCF, 2016: 5). As they have further argued, “The TMP lacks vision and disregards the latest technology. As soon as it is built, its obsolescence will prove expensive and embarrassing to Penang "in the eyes of the world"' (Penang Forum, 2016b: np). Through such claims, the BCF critique seeks to counter the official representation of the PTMP project as a way to 'showcase modern Malaysia' and to gain recognition as a 'world class international city', as discussed in the introduction to this paper. Such 'counterglobalization' strategies, as Massey (2011) has written, are an important means by which worlding cities seek to challenge and, in the process, redefine what it means to be a 'world class' city.

In addition to these criticisms, a recurring theme in the BCF Report is an aesthetic concern related to the visually obtrusive nature of the infrastructural projects on the local landscape. As it argues: "elevated monorail does not suit the Penang Landscape, is low value for money, unsafe and way past its prime - many would say obsolete” (BCF 2016, np). Such rhetoric relates to Ghertner's (2011b) concept of aesthetic governmentality which refers to ideas of how the city should look becomes a mode of governing land use. For instance, the website detailing their BCF plan makes extensive use of computer generated graphics which embed elevated monorail or expressways over existing George Town landscapes (see Figure 2). It also stresses the in/direct nuisance elements arising from such infrastructure, including noise and pollution from fumes. The effect is thus to demonstrate how these various structures will overshadow the historic townscape and threaten its UNESCO World Heritage status, which they state is "a key driver of the tourism industry which generates almost $50 \%$ of 
our GDP” (Penang Forum, 2016a: 31). As I have illustrated in earlier work (Connolly, 2017), the UNESCO World Heritage status in George Town can be used as a powerful political tool for prompting government action.

Relatedly, it is argued in the BCF plan that the LRT and Monorail infrastructure "will forever alter the nature of [Penang's] built environment" (Penang Forum, 2016a: 31). It further states that the elevated structures would not only impede access to disabled users, but would also take up significantly more space in the built environment, "requiring greater land acquisition and much greater tree loss" (Penang Forum, 2016a: 31). As such, the BCF critique argued that by advancing massive road and tunnel expansion, the "car-centric TMP imperils Penang's heritage and fragile ecology, increasing our carbon emissions without a thought for future generations" (Penang Forum, 2016b: np). On the other hand, the BCF report notes that, "trams are less intrusive, aesthetically and visually more pleasing" than LRT and monorail, and use photos of modern tram and BRT systems from other cities to illustrate their point.

$<$ Figure 2 about here: Penang Forum visualization of what the proposed double deck highway would look like along Perak Road in Penang (Penang Forum, 2016a: 23; reproduced with permission).>

In fact, the unsuitability of monorails for Penang, and the idea of building trams was initially supported by the State Government, in 2013, when Chief Minister Lim Guan Eng claimed that the proposal by Barisan National (a coalition of opposition political parties in Penang) for a monorail "is inappropriate for a world heritage city like Penang, as its elevated structure will destroy Penang's charms" (Netto, 2013: np). Though Lim also sought to build more roads, this was largely to replace existing roads which could then make way for tram lines. At this time, the State Government was also quite responsive to the demands of civil society groups like Penang Forum, and willing to work together to do "what's best for Penang" (Netto, 2013: np). As such, a major concern of the Penang Forum now is the lack of transparency on behalf of the government, and the sudden reversal in attitudes regarding transport infrastructure in Penang.

In illustrating the potential problems with a public transit system based on LRT and Monorail infrastructure, the BCF report points to numerous cities where such projects have failed. Most notably, Malaysia's capital Kuala Lumpur (KL) is frequently cited as a model that Penang should avoid following. This is because KL has a large and rather disconnected transit system, comprised of highways, LRT and monorail lines, similar to what the PTMP envisions for Penang. Consequently, there is an entire section of the BCF document titled 'Don't turn Penang into KL'. This section of the 
report argues how the experience of the Klang Valley transit system (surrounding KL) indicates how: "elevated structures destroy communities who live in their shadows". It also notes how the operators of the KL monorail and LRT lines declared insolvency due to the unviability of the projects. In this case, the BCF report notes that the Federal government bought out the operators to continue operating the systems at a loss, but that in the Penang context, the financial burden would be borne largely by Penangites.

In highlighting the potential financial burdens of the PTMP, the BCF Report points to several other cities with monorail systems which "find themselves in financial distress", including: Mumbai, Las Vegas, Moscow, Seattle, Sydney, and Moscow. As argued in the BCF Report, the monorail systems in these cities have cost taxpayers millions of dollars, leading to some of them being torn down. The report makes further reference to other cities nearer to Penang which abandoned their monorail projects during construction due to high costs, including Jakarta, Putrajaya and Malacca, Malaysia. As the BCF notes, Malacca's monorail was abandoned due to technical problems in its first year of operation and has subsequently been a visual and economic blight on the city (Penang Forum, 2016a: 9). ${ }^{8}$ It also explains how Jakarta launched too many mega transport projects at the same time, only for some of them to later be delayed or abandoned. The Jakarta monorail, for instance, was launched, aborted, resumed and abandoned over the course of 11 years. According to Davidson and Kutz (2015), failed infrastructure projects is the primary reason why city governments are forced into austerity or declare bankruptcy. As such the Penang Forum is concerned that Penang will suffer the same fate if these infrastructural projects are not successful.

Similarly, the BCF Report makes frequent use of comparisons to other cities in supporting their arguments against the PTMP. Other than news clippings about progressive and 'eco-friendly' urban planning models in cities like Copenhagen, Oslo and Adelaide; the BCF Report largely makes reference to cities in transitioning economies which have constructed successful public transit models based around BRT and Tram infrastructure. As noted above, the BCF plan does not make explicit reference to the oft-cited 'global cities' in developed countries due to incomparable population size, land area, and land-labor costs. For example, the BCF Report notes that "London, Tokyo and New York are large cities that require multiple modes of well integrated public transport systems" (Penang Forum, 2016a: 9). Moreover, transport systems in such cities were developed gradually over time as the

\footnotetext{
${ }^{8}$ As of December 2017, the Malacca Monorail is now back in operation, but only covers $1.6 \mathrm{~km}$ and has a maximum capacity of 30 travellers per hour, and is solely used for tourism purposes (The Star Online, 3 December, 2017).
} 
population and urban area expanded. Penang, on the other hand, is more-or-less starting from scratch, and thus requires a more integrated mode of transit that is cheaper and quicker to build.

As such, it is typically cities outside of the global North that are targeted as referent-points as they can be seen as more realistic and appropriate comparisons for Penang. Rio de Janeiro, for example, has both BRT and tram systems which were each built over three year periods, costing about four times less than the proposed LRT and monorail system in Penang, while serving a much larger urban area and population. Other cities with successful tram systems referred to are Kaohsiung, and Suzhou, China and Casablanca, Morocco, which are all located in middle income countries, as identified by the World Bank (World Bank, 2016). Of these, Kaohsiung is specifically noted as having the most similarities with Penang, including being a secondary city, being an island port city, and having a similar urban area and population size. Rio de Janeiro and Suzhou are also UNESCO World Heritage Cities, which creates further parallels with Penang. This underscores Robinson's (2002) contention that a more cosmopolitan urban theory can be more helpful in understanding the world, and in imagining possible urban futures (546).

One of the more heated debates between proponents of the SRS Consortium Proposal for the PTMP and the Better Cheaper Faster vision related to the regeneration of an area on the edge of the George Town World Heritage Site, known as Sia Boey. This site was originally part and parcel of the surrounding pre-war shophouses in George Town, but was severely affected by the construction of KOMTAR and the associated 'New Urban Centre' development in the 1980s. The buildings were subsequently abandoned, and have been derelict since the 1990s. In 2015, the Penang Development Corporation (PDC) embarked on an RM100 million project called 'Sia Boey: Reborn', to turn the area into a 'Heritage Arts District'. This was described as an effort to "capitalize on art and heritage as the economic catalyst to drive urban regeneration” (MyPenang, 2015). Though one Penang Forum member who worked on the project had reservations about it turning into a 'Singapore style development' (interview, 17 February 2017), it was still generally seen as a positive development for the area. ${ }^{9}$ Such reservations are quite commonly invoked by critical residents civil society actors in Malaysia who see Singapore as a model not to replicate, arguing for the preservation of Penang's unique cultural and physical characteristics.

However, barely six months afterwards, the State Government cancelled the Sia Boey: Reborn project and announced that it would instead become the site of a major transport hub for the LRT and

\footnotetext{
${ }^{9}$ Thus, this point speaks to the "frictions" and tensions involved in the assembling of 'worlding' cities, in which "parts of elsewhere[s]" are both aspired to, but also resisted (Tsing, 2000; Allen and Cochrane, 2007: 121).
} 
two monorail lines to be built as part of the PTMP. Unsurprisingly, this was a highly controversial announcement, as it stands in opposition to the BCF alternative put forth by the Penang Forum. While the BCF proposal also calls for a tram interchange to be located at the site, this would still be compatible with the Heritage Arts District, being smaller and less structurally demanding. Moreover, the BCF proposal would also retain the row of pre-war shophouses present on the site, rather than demolishing them as in the State's proposal. This can be seen in Figure 3, which shows an artists impression of the contrast between the SRS and BCF proposals for the site, in relation to the current land use, stressing the space consumed by the raised LRT infrastructure.

$<$ FIGURE 3 about here: Artist's illustration contrasting the BCF (bottom) and SRS (middle) proposals for the Sia Boey Site, in comparison to the current land use (top) (Penang Forum 2016a: 57), reproduced with permission.>

Following the State Government's announcement of their plan for the site, a former city councillor and Penang Forum member wrote a letter to UNESCO to alert them of Sia Boey's fate, who in turn notified the Malaysian National Heritage Department. The National Heritage Department then issued an interim protection order for the Sia Boey site, which required approval and enforcement from the Penang State Government. Chief Minister Lim Guan Eng responded negatively to the UNESCO letter, saying it was "like a stab in the back" given that it was written by an MBPP Councillor (Mayberry, 2016: np). Lim explained that the PTMP is not only a 'game changer' as boasted in the SRS report, but also a "life changer that can affect every citizen in the state, and will provide for the economic prosperity of Penang until 2050" (Mayberry, 2016: np). Such comments are evocative of the attitude of the Malaysian government's narrow focus on Development as the way forward for Malaysia. It also highlights the extent to which constructive criticism on behalf of civil society and other stakeholders is (not) valued by the government, as documented in previous work (Connolly, 2017).

The case of Sia Boey is also illustrative of the limits of grassroots worlding practices, and resistances to the developmental world city models pushed forward by neoliberalizing governments. While the Penang case provides more grounds for optimism than the studies of civic governmentality in South Asian cities mentioned above (e.g. Ellis, 2012; Ghertner, 2011b; Roy, 2009); the BCF movement - and other forms of grassroots activism in Penang - exist largely in reaction to already established plans advanced by state actors. Therefore, they tend to have limited scope in really altering the status quo, as 
plans have already been made, and contracts signed with developers. As such, what is needed is a form of civic governmentally that is less reactionary, and can set the agenda for globalizing cities before extensive redevelopment projects are announced. One example in this regard is the case of Yangon, Myanmar, whereby the Yangon Heritage Trust (YHT) has been pro-active in making alliances with key stakeholders in the urban arena and setting out a framework for a 'liveable Yangon'. Much like the Penang case, this vision for Yangon is entered on combining conservation and development, which can help: "avoid the mistakes of its regional neighbours" (YHT, 2018). Thus, future studies of urban governance and grassroots worlding strategies could focus on the strategies used by organizations like the YHT to develop more inclusive and place-appropriate cities.

\section{Conclusion}

This paper has reviewed two competing plans for the future of Penang, and particularly its Transport Master Plan, known as the PTMP. By contrasting the official plan for the PTMP endorsed by the State Government, and the alternative 'Better, Cheaper, Faster' proposal put forth by civil society groups; this paper has sought to question what counts as a 'global' or 'world' cities, and identify alternative strategies that are being developed to achieve more inclusive and socio-ecologically just forms of being global. The strategies documented here include various forms of knowledge production, public consultation, and public campaigns put together by the Penang Forum and associated actors. In this regard, the paper contributes to previous work on civic governmentality which has sought to highlight the technologies of governance and participation that are central to struggles over the development of aspirational world cities in Asia (see Roy, 2009; Ellis, 2012).

In doing so, the paper has sought to highlight urban transportation infrastructure as one key site of worlding, which has to date not been sufficiently examined in the literature. This is despite the widespread recognition of such infrastructural networks in urban development strategies of cities like Sydney, Kuala Lumpur, and Bogota (Baker and Ruming, 2014; Bunnell, 2004; Montero, 2017). Dominguez Rubio and Fogué (2013) have argued that the increasing politicization of infrastructure in public life, including the increasing privatization of its provision, presents not only a target for political opposition, but also an opportunity to rethink the type of urban spaces in which citizens want to live. The case also underscores Pojani and Stead's (2015) point that focusing on transport infrastructure in smaller and medium-sized cities is crucial to achieving substantial progress towards sustainable urban development as they hold greater potential and flexibility for sustainable transformations in land use and planning. As the BCF proposal has demonstrated, their alternative vision for Penang's Transport 
Master Plan would be more environmentally friendly, present less externalities in the form of noise pollution, preserve the city's heritage, and be more accessible to the entire population. It would also be less capital intensive that the PTMP plan, which would pose a substantial financial burden to Penangites in the long run, and only exacerbate the city's congestion problems.

Finally, and perhaps most importantly, the paper has sought to bring attention to the important role of 'ordinary' cities in urban worlding strategies, which has been largely overlooked in the extant literature on worlding and inter-referencing strategies. As Bunnell (2004) has argued, many postcolonial approaches to 'modernity' or 'globality' are premised on the replication of Western forms of development (see also Ong, 1999). Yet, as Huang and Chang (1996: 99) have observed, one can easily wonder how a city can be truly world class if it merely replicates the architectural and urban design concepts set by others. Instead, they suggest that 'world cities' should be those that are bold enough to test new ideas and challenge the city's place within wider global structures (Massey, 2011). As such, this paper has sought to expand the concept of wording so as to assist in imagining possible city futures beyond the experiences of select world and global cities. While the concept of wording cities has been useful for broadening understanding of what counts as being global; work in this areas still has a rather limited understanding the complex and shifting geographies of inter-city comparison, referencing and modeling. The case of Penang thus demonstrates how civil society actors have cast their sights 'outwards' to comparable cities around the world, rather than merely 'upwards' to global and megacities that only limit imaginations of possible urban futures.

\section{Acknowledgements}

Research for this paper was made possibly by funding from the Asia Research Institute, National University of Singapore (NUS). I am grateful to the Penang Forum for allowing me to reproduce the figures included in this article. I would like to thank Erik Swyngedouw, Rachel Bok, and members of the Politics Economies and Space (PEAS) Research Group at NUS for helpful comments on previous drafts of this paper. I also appreciate the suggestions of three anonymous reviewers which helped to clarify my arguments and writing.

\section{References}

Allen J and Cochrane A (2007) Beyond the Territorial Fix: Regional Assemblages, Politics and Power. Regional Studies 41(9): 1161-1175. DOI: 10.1080/00343400701543348. 
Baker T and Ruming K (2015) Making 'Global Sydney': Spatial Imaginaries, Worlding and Strategic Plans. International Journal of Urban and Regional Research 39(1): 62-78.

Barau AS (2017) Tension in the periphery: An analysis of spatial, public and corporate views on landscape change in Iskandar Malaysia. Landscape and Urban Planning 165: 256-266.

Baviskar A (2003) Between violence and desire: space, power, and identity in the making of metropolitan Delhi. International Social Science Journal 55(175): 89-98.

Blok A (2014) Worlding cities through their climate projects?: Eco-housing assemblages, cosmopolitics and comparisons. City 18(3): 269-286. DOI: 10.1080/13604813.2014.906715.

Brenner N (1999) Globalisation as Reterritorialisation: The Re-scaling of Urban Governance in the European Union. Urban Studies 36(3): 431-451. DOI: 10.1080/0042098993466.

Britton, E. 2016. 'A Letter of Concern', in: Penang Forum, Better Cheaper Faster: Penang Transport Master Plan. Available at: www.bettercheaperfaster.my (accessed 12 March 2018).

Bunnell T (2002) Cities for nations? Examining the city-nation-state relation in Information Age Malaysia. International Journal of Urban and Regional Research 26(2): 284-298.

Bunnell T (2004) Malaysia, modernity and the multimedia super corridor: a critical geography of intelligent landscapes. London; New York: RoutledgeCurzon.

Bunnell T and Marolt P (2014) Commentary. Environment and Planning D: Society and Space 32(3): 381-385. DOI: $10.1068 / \mathrm{d} 14043 \mathrm{~cm}$.

Chatterji R (2005) Plans, habitation, and slum redevelopment: The production of community in

Dharavi, Mumbai. Contributions to Indian Sociology 39(2):197-218

Christof K (2018) The Citizen Professional, Mediatization, and the Creation of a Public Domain. Culture Unbound 9(3): 279-306.

Connolly C (2017) Whose landscape, whose heritage? Landscape politics of 'swiftlet farming' in a World Heritage City. Landscape Research 42(3): 307-320.

Davidson M and Kutz W (2015) Grassroots austerity: municipal bankruptcy from below in Vallejo, California. Environment and Planning A 47(7): 1440-1459.

Douglass M (1998) World City Formation on the Asia Pacific Rim: Poverty, 'Everyday' Forms of Civil Society and Environmental Management. In: Douglass M and Friedmann J (eds) Cities for citizens: planning and the rise of civil society in a global age. Chichester, England ; New York: J. Wiley, pp. 107-138.

Ellis R (2012) “A World Class City of Your Own!”: Civic Governmentality in Chennai, India. Antipode 44(4): 1143-1160. DOI: 10.1111/j.1467-8330.2011.00958.x.

Ghertner DA (2011a) Gentrifying the State, Gentrifying Participation: Elite Governance Programs in Delhi: Gentrifying the local state in India. International Journal of Urban and Regional Research 35(3): 504-532. DOI: 10.1111/j.1468-2427.2011.01043.x. 
Ghertner DA (2011b) Rule by Aesthetics: World-Class City Making in Delhi. In: Ong A and Roy A (eds) Worlding cities: Asian experiments and the art of being global. Studies in urban and social change. Chichester, West Sussex ; Malden, MA: Wiley-Blackwell, pp. 279-306.

Goh D and Bunnell T (2013) Recentering Southeast Asian Cities. International Journal of Urban and Regional Research 37(3): 825-33.

Graham S and Marvin S (2002) Splintering urbanism networked infrastructures, technological mobilities and the urban condition. London: Routledge.

Hall T and Hubbard P (eds) (1998) The entrepreneurial city: geographies of politics, regime, and representation. Chichester; New York: Wiley.

Harvey D (1989) From Managerialism to Entrepreneurialism: The Transformation in Urban Governance in Late Capitalism. Geografiska Annaler. Series B, Human Geography 71(1): 3.

Hezri A (2016) The sustainability shift: refashioning Malaysia's future. Penang: Areca Books

Huang S and Chang TC (2003) Selective Disclosure: Romancing the Singapore River. In: Goh RBH and Yeoh BSA (eds) Theorizing the Southeast Asian city as text: urban landscapes, cultural documents, and interpretative experiences. Singapore ; New Jersey: World Scientific, pp. 77108.

Jenkins G and King VT (2003) Heritage and development in a Malaysian city: George Town under threat? Indonesia and the Malay World 31(89): 44-57. DOI: 10.1080/13639810304441.

Ku AS (2012) Remaking places and fashioning an opposition discourse: struggle over the Star Ferry pier and the Queen's pier in Hong Kong. Environment and Planning D: Society and Space 30(1): 5-22. DOI: 10.1068/d16409.

Liew KK and Pang N (2015) Neoliberal visions, post-capitalist memories: Heritage politics and the counter-mapping of Singapore's cityscape. Ethnography 16(3): 331-351.

Mayberry K (2016) Penang split over transport infrastructure plan. Nikkei Asian Review, 13 October. Available at: http://asia.nikkei.com/Politics-Economy/Policy-Politics/Penang-split-overtransport-infrastructure-plan (accessed 19 October 2016).

Massey D (2011) A Counterhegemonic Relationality of Place. In: Mobile Urbanism" Cities and policymaking in the Global Age. Globalization and Community. Minneapolis: University of Minnesota Press, pp. 1-14.

McCann E, Roy A and Ward K (2013) Assembling/Worlding Cities. Urban Geography 34(5): 581589. DOI: $10.1080 / 02723638.2013 .793905$.

McFarlane C (2011) Encountering, describing and transforming urbanism: Concluding reflections on assemblage and urban criticality. City 15(6): 731-739.

Montero S (2017) Worlding Bogotá's Ciclovía: From Urban Experiment to International "Best Practice”. Latin American Perspectives 44(2): 111-131. DOI: 10.1177/0094582X16668310. 
MyPenang (2015) Sia Boey: Reborn. Available at:

http://www.mypenang.gov.my/itemfull.aspx?id=5659 (accessed 31 March 2017).

Netto A (2013) Tunnel-highways project: Guan Eng responds. anilnetto.com. Available at: http://anilnetto.com/democracy/civil-society/tunnel-highway-projects-guan-eng-responds/ (accessed 12 March 2018).

Netto A (2017) City councillor nominated by Penang Forum just delivered a brilliant address at an MBPP full council meeting. anilnetto.com. Available at: http://anilnetto.com/democracy/civilsociety/city-councillor-nominated-penang-forum-just-delivered-brilliant-address-mbpp-fullcouncil-meeting/ (accessed 10 November 2017).

Ng E (2016) The Big Read: Penang takes a leaf from S'pore, and bids to become a competitor. Today (Malaysia), 14 May. Available at: http://www.todayonline.com/world/asia/big-read-penangtakes-leaf-spore-and-bids-become-competitor (accessed 9 December 2016).

Ngui A (2017) Fate of Penang Transport Master Plan hangs in the balance (Updated). The Sun Daily, 26 August. Balik Pulau, Malaysia. Available at:

http://www.thesundaily.my/news/2017/08/26/fate-penang-transport-master-plan-hangs-balanceupdated.

Ong A (1999) Flexible citizenship: the cultural logics of transnationality. Durham: Duke University Press.

Ong A (2011) Introduction: Worlding Cities, or the Art of Being Global. In: Roy A and Ong A (eds.), Worlding cities: Asian experiments and the art of being global. Studies in urban and social change, Malden, MA: Wiley-Blackwell, pp. 1-26.

Peck J and Theodore N (2010) Mobilizing policy: Models, methods, and mutations. Geoforum 41(2): 169-174. DOI: 10.1016/j.geoforum.2010.01.002.

Penang Forum (2012) About Us. Available at: https://penangforum.net/about/ (accessed 12 March 2018).

Penang Forum (2016a) Better Cheaper Faster: Penang Transport Master Plan. July. Available at: www.bettercheaperfaster.my (accessed 12 March 2018).

Penang Forum (2016b) The Penang Transport Master Plan: Response from NGOs. Available at: http://www.pht.org.my/the-penang-transport-master-plan-response-from-ngos-concise-version/.

Penang State Government (2016) Penang Transport Master Plan. Available at: http://pgmasterplan.penang.gov.my/index.php/en/2016-02-26-03-12-57 (accessed 28 March 2017).

Pojani D and Stead D (2015) Sustainable Urban Transport in the Developing World: Beyond Megacities. Sustainability 7(6): 7784-7805. DOI: 10.3390/su7067784.

Robinson J (2002) Global and world cities: a view from off the map. International Journal of Urban and Regional Research 26(3): 531-554. DOI: 10.1111/1468-2427.00397. 
Roy A (2009) Civic Governmentality: The Politics of Inclusion in Beirut and Mumbai. Antipode 41(1): 159-179. DOI: 10.1111/j.1467-8330.2008.00660.x.

Roy A (2011) Urbanisms, worlding practices and the theory of planning. Planning Theory 10(1): 6-15. DOI: $10.1177 / 1473095210386065$.

Roy A and Ong A (eds) (2011) Worlding cities: Asian experiments and the art of being global. Studies in urban and social change. Chichester, West Sussex ; Malden, MA: Wiley-Blackwell.

Shatkin G (2011) Planning Privatopolis: Representation and Contestation in the Development of Urban Integrated Mega-Projects. In: Ong A and Roy A (eds) Worlding cities: Asian experiments and the art of being global. Studies in urban and social change. Chichester, West Sussex ; Malden, MA: Wiley-Blackwell, pp. 77-97.

Simone AM (2001) On The Worlding of African Cities. African Studies Review 44(2): 15-41.

SRS Consortium (2015), Penang Transport Master Plan Request for Proposal, Vol. 1.

Swyngedouw E (2005) Governance Innovation and the Citizen: The Janus Face of Governancebeyond-the-State. Urban Studies 42(11): 1991-2006. DOI: 10.1080/00420980500279869.

Swyngedouw E (2009) The Antinomies of the Postpolitical City: In Search of a Democratic Politics of Environmental Production. International Journal of Urban and Regional Research 33(3): 601620. DOI: 10.1111/j.1468-2427.2009.00859.x.

Tsing AL (2005) Friction: an ethnography of global connection. Princeton, N.J: Princeton University Press.

Wetzstein S (2013) Globalising Economic Governance, Political Projects, and Spatial Imaginaries: Insights from Four Australasian ${ }^{1}$ Cities: Globalising Economic Governance, Political Projects, and Spatial Imaginaries. Geographical Research 51(1): 71-84.

Wood A (2014) Learning through Policy Tourism: Circulating Bus Rapid Transit from South America to South Africa. Environment and Planning A 46(11): 2654-2669.

World Bank (2016) Middle Income Countries. Available at: http://www.worldbank.org/en/country/mic (accessed 19 February, 2018).

Yangon Heritage Trust (YHT) (2018) Yangon Heritage Strategy. Available at: http://www.yhtliveableyangon.org/en/home/ (accessed 15 August, 2018). 


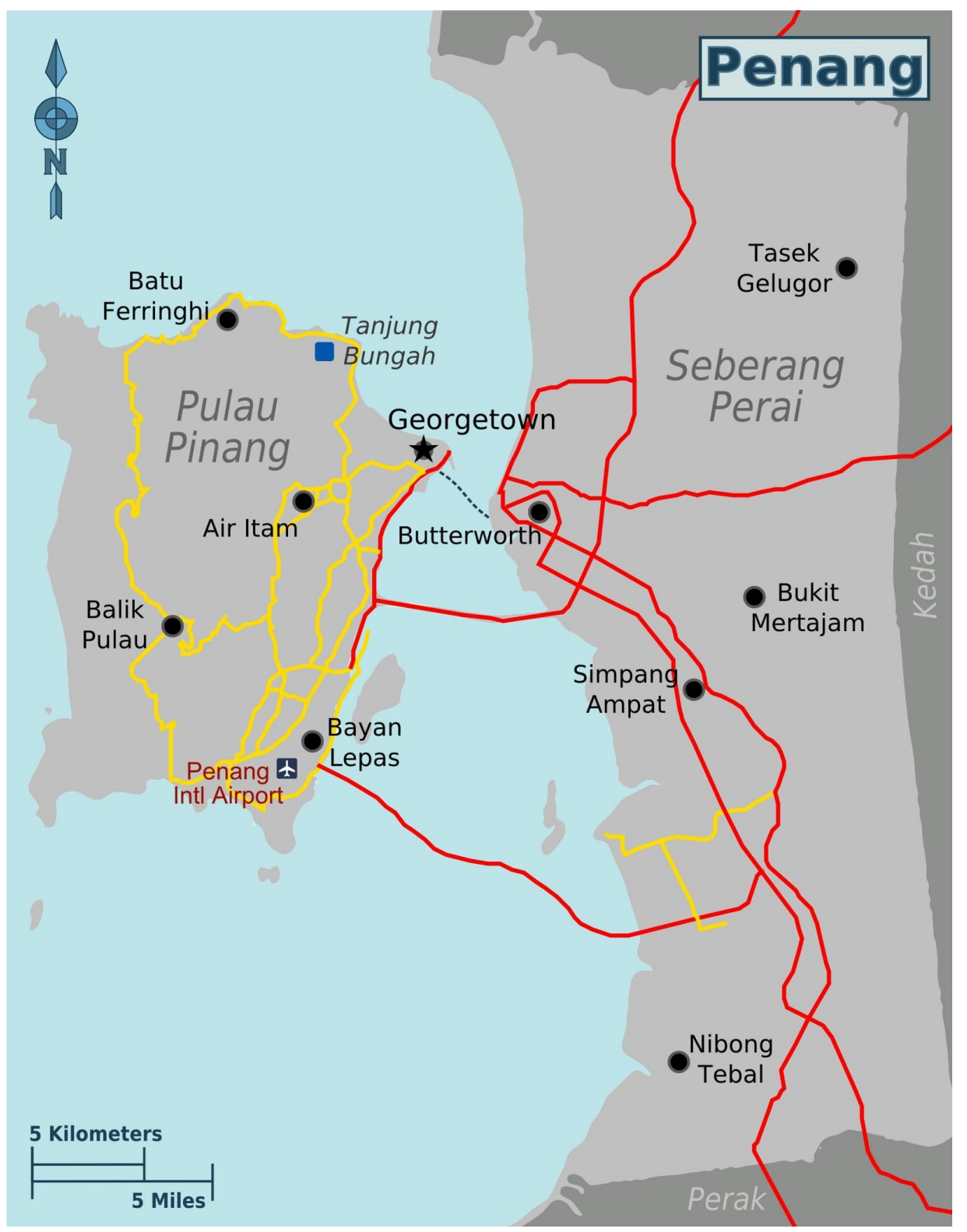

Map of George Town and Penang State. Photo Credit: "Penang Wikivoyage Map"; Wikimedia Commons user Torty3; (https://commons. wikimedia.org/w/index.php?curid=31257157); image reproduced under a Creative Commons license.

$571 \times 735 \mathrm{~mm}(72 \times 72 \mathrm{DPI})$ 


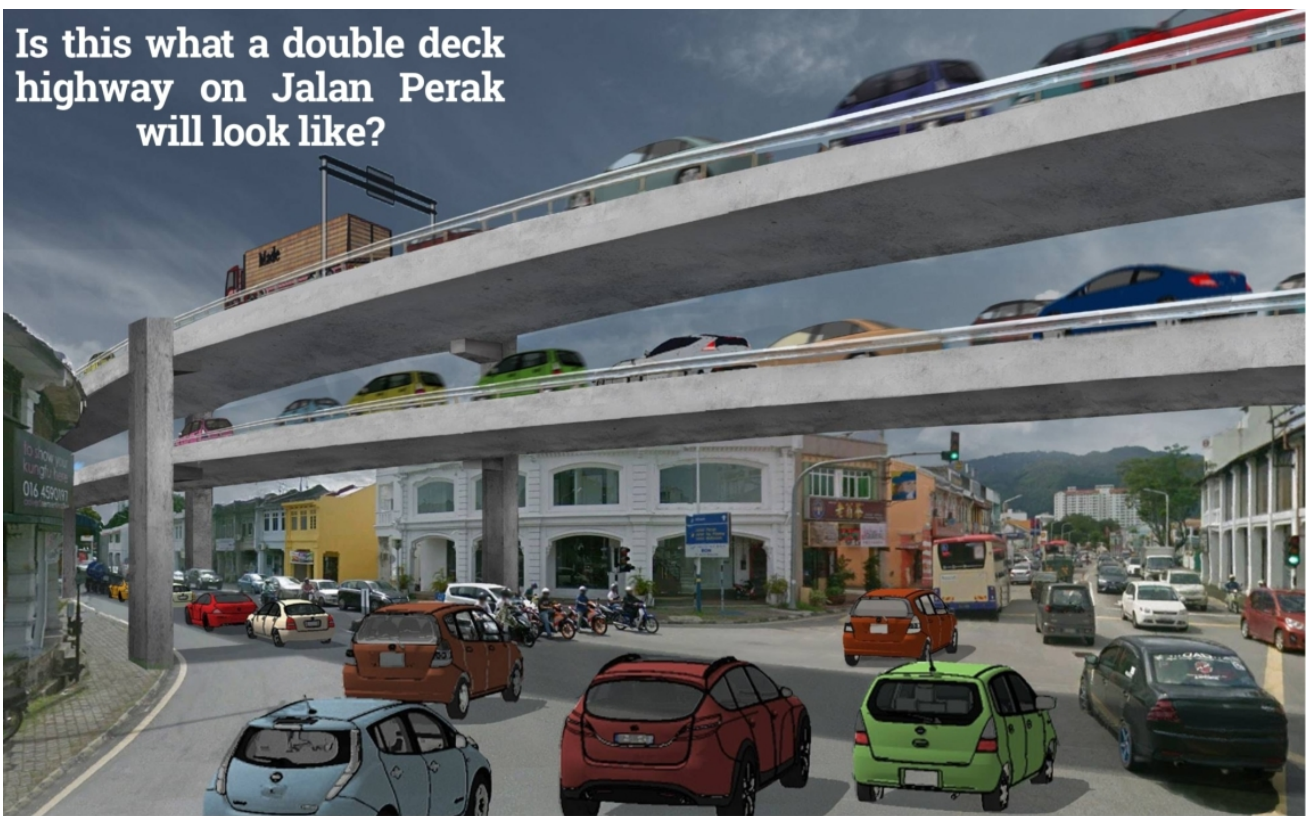

Penang Forum visualization of what the proposed double deck highway would look like along Perak Road in Penang (Penang Forum, 2016a: 23; reproduced with permission).

$747 \times 466 \mathrm{~mm}(72 \times 72 \mathrm{DPI})$ 

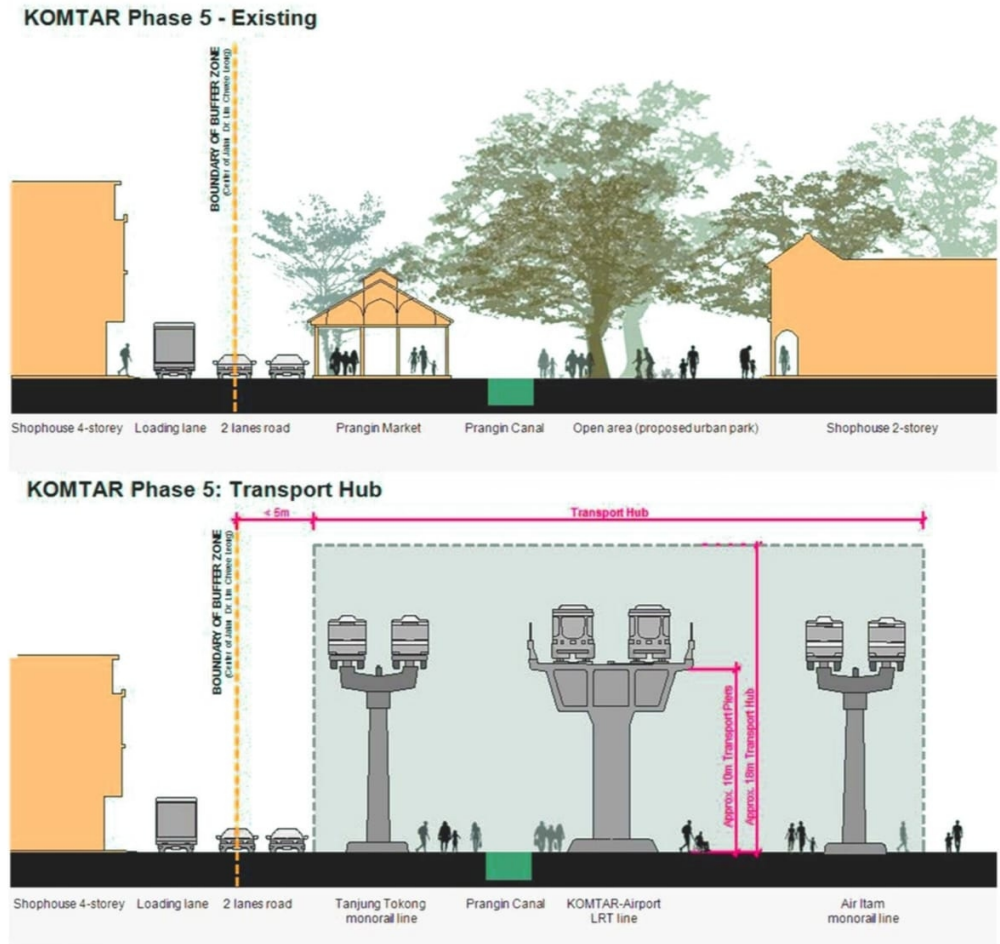

KOMTAR Phase $5 \cdot$ Tram

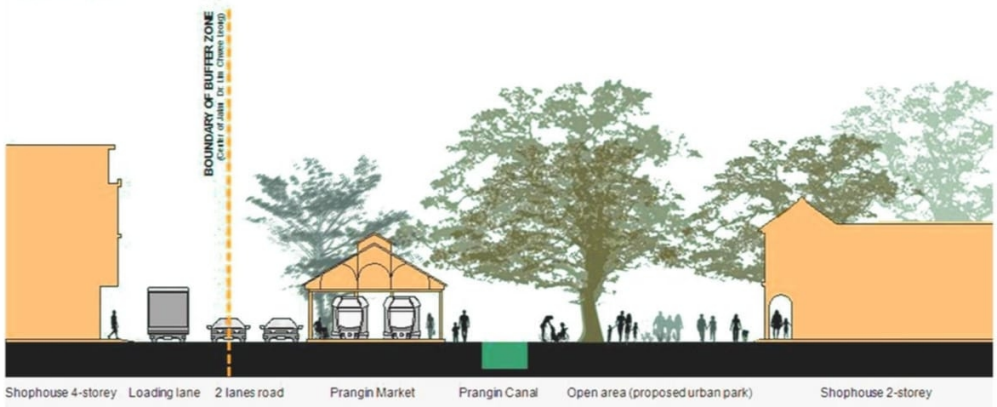

Artist's illustration contrasting the BCF (bottom) and SRS (middle) proposals for the Sia Boey Site, in comparison to the current land use (top) (Penang Forum 2016a: 57), reproduced with permission.

$455 \times 647 \mathrm{~mm}(72 \times 72$ DPI $)$ 